Article

\title{
Environmental Parametric Cost Model in Oil and Gas EPC Contracts
}

\author{
Madjid Abbaspour ${ }^{1}$ (D), Sanaz Toutounchian ${ }^{2, *}$, Tooraj Dana ${ }^{2}$, Zahra Abedi ${ }^{2}$ and \\ Solmaz Toutounchian ${ }^{2}$ \\ 1 School of Mechanical Engineering, Sharif University of Technology, Tehran, Iran; abbpor@sharif.edu \\ 2 Department of Environment and Energy, Science and Research Branch, Islamic Azad University, Tehran, \\ Iran; tooraj_da@yahoo.com (T.D.); abedi2015@yahoo.com (Z.A.); solmaztoutounchian@yahoo.com (S.T.) \\ * Correspondence: stoutounchian@yahoo.com; Tel.: +98-912-6352615
}

Received: 5 December 2017; Accepted: 11 January 2018; Published: 18 January 2018

\begin{abstract}
This study aims at identifying the parameters that govern the environmental costs in oil and gas projects. An initial conceptual model was proposed. Next, the costs of environmental management work packages were estimated, separately and were applied in project control tools (WBS/CBS). Then, an environmental parametric cost model was designed to determine the environmental costs and relevant weighting factors. The suggested model can be considered as an innovative approach to designate the environmental indicators in oil and gas projects. The validity of variables was investigated based on Delphi method. The results indicated that the project environmental management's weighting factor is $0.87 \%$ of total project's weighting factor.
\end{abstract}

Keywords: work breakdown structure (WBS); cost breakdown structure (CBS); environmental management costs; EPC contracts; weighting factor (WF); parametric model

\section{Introduction}

Today, the growth and development of industry is inevitable and it is impossible and unreasonable to avoid it. However, the adverse effects of the environmental aspects of human activities can be eliminated or reduced by adhering to the principles of sustainable development. Almost all projects are planned and implemented in a social, economic and environmental context and have positive and negative effects. Organizations are increasingly accountable for the unwanted consequences of their projects, as well as for their impacts on the people, the economy and the environment, even after their projects have been completed [1]. Therefore, it is believed that sustainable industrial development requires serious attention to environmental management in operations. In proper execution of oil and gas engineering, procurement and construction (EPC) contracts, paying attention to ISO 14001 standards and International Association of Oil and Gas Producers (IOGP) guidelines is fundamental and the contractors ought to follow the contract clauses through Health, Safety and Environmental (HSE) Plan. The IOGP recommended oil and gas companies/contractors fulfil HSE-MS requirements in a contract environment [2]. Management of HSE in a business environment where a client and one or more contractors work together requires co-operation between all parties and a clear definition of the tasks and responsibilities of each of the parties during different phases of project. Therefore, supplying the financial resources of a contract along with forecasting the final costs, improves decision-making, budget designation, time schedule, related activities and responsible authority. On this basis, the clauses, which have directly financial effects on project, are of high importance. Although, there is a specific payment system for the contractor's technical and engineering affairs, unfortunately, no specific financial payment process is reported for environmental parameters of contract. It is obvious that the legal requirements and economic incentives shall be considered in contracts to improve the environmental conditions. Since the clients monitor the 
contractors' executions, if contracts' environmental clauses are missed, the contractors may not care of the environmental issues in implementation phase.

The present study aims to design an environmental parametric cost model via finding the environmental parameters to assist in cost estimation during the execution of oil and gas EPC contracts and to increase their environmental performance and sustainable development in oil and gas industry. Finally, these questions are going to be answered: "Which environmental management parameters are required to be incorporated into the EPC contracts?", "How are these costs estimated?" and "How can environmental parameters be incorporated into project invoices and produce a progress report?".

Recently, environmental concerns have been increased and industrial sectors have obliged to pay more attention to the environmental impacts of their activities [3]. De Burgos-Jimenez et al. [4] and Muhammad [5] discussed the environmental tendency of organizations and their possible consequences on enhancement of financial performance. A significant amount of literatures has been published to indicate and analyze the relationship between environmental activities and performance of organizations [6-8]. Rao and Holt [9] believed that control measures and preventive strategies could allow companies to make a significant cost savings. On the other hand, Darnall and Edwards [10] claimed that environmental regulations impose extra costs on companies and they have to decrease the diverse impact of their activities to comply with the international regulations and standards. Obviously, in long run complying with these regulations will decrease the final expense of related companies. Many studies have been carried out on project cost estimation methods [11-18]. To date several conceptual frameworks have been proposed to identify the various costs associated with waste and pollution, such as Life Cycle Assessment (LCA); Environmental Cost Accounting (ECA); Full Cost Accounting (FCA); and Total Cost Assessment (TCA) [19,20]. In the current business environment, organizations need to implement proper strategies to manage costs. Henri et al. [21] expressed the needs to examine the environmental management costs at both strategic and operational level. Identification and tracking of environmental management costs can improve awareness of organizational managers in a contract environment [22,23]. Rannou and Henri believed that monitoring of environmental costs allows organizations to estimate the real costs of their products and services [21]. The EPA has defined environmental management costs as those costs that have direct financial impacts on companies (internal cost) and the costs to individuals, society and the environment for which the company is not accountable (external cost) [24].

The extractive industry (including the oil and gas sector) is universally considered as one of the most environmentally sensitive industries [25]. In the extractive industry, particularly the oil and gas sector, companies extract from natural sources [26]. This depletion of natural sources could affect the company's reputation, so companies might be less transparent about their financial issues [27]. In the extractive industry, most of the companies do not disclose additional information in their reports and financial statements in relation to their activities [28]. Russell and Jenkins (2010) stated that the financial report is one of the tools that companies use for marketing their products because the oil and gas industry has become very significant for many environmental and political interests. However, they suggested that there should be a comprehensive accounting standard for the oil and gas industry to cover several issues [28]. In the oil and gas industry, the environmental cost can be divided into two categories as Environmental Contamination Treatment Cost and The Restoration and Environmental Reclamation Cost. Beck et al. [27] have used content analysis as a method for their studies in the field of environmental accounting. Content analysis can be used in both quantitative and qualitative methods [29]. In general, there are two types of environmental costs including Private (internal) costs and Externalities (societal) costs. Private or internal costs are costs that directly have an impact on company's bottom line. While, externalities or societal costs encompass the costs to individuals, society and the environment for which a company is not accountable [30]. Bassey, Oba and Onyah (2013) critically analyzed the extent of the implications of environmental cost management and its impact on the output of oil and gas companies in Nigeria from 2001 to 2010 [31]. Findings of their study revealed that there is a significant relationship between the parameters that influence 
environmental cost management and output of oil and gas produced in Nigeria. Olalekan and Jumoke (2017) declared that Environmental Management Accounting (EMA) deals with the management of environmental costs that directly affect organizational financial performance, which are referred to as private or internal costs [30]. In most studies in the field of extractive industry, EMA is used to manage environmental costs [32,33].

In conclusion, no research has reported environmental parameters costs in the execution of oil and gas EPC contracts. In some cases, environmental parameters have been presented based on compliance with environmental management standard (ISO 14001). Even in such cases, the presented parameters are not complete. Whereas environmental control and monitoring is mostly done through environmental performance assessment, none of the studies has pointed out to the contractual monitoring by client. Despite applying various methods to identify and budget the environmental costs, the contractual payment mechanism is not clear yet.

Therefore, in an innovative approach, this study aims to identify the effective environmental management parameters and present a proper environmental budgeting in oil and gas EPC contracts.

It should be noted that, PMI (2013) has defined the project as "a temporary endeavor undertaken to create a unique product or service" [34]. Therefore, this research is not included the external costs due to project time limitation, specific and short time implementation and lack of exploitation phase in project. Obviously, the external cost is measurable in organizations or contracts, which include production phase. In addition, there are certain factors (such as number of contractors; different executive phases; time duration of project implementation; and existence of various types of operations in the construction, installation and commissioning/operation projects) that pose serious problems to the external costs estimation. In conclusion, it is recommended estimate the externality for future work.

\section{Materials and Methods}

The methodology in this study is demonstrated in Figure 1. On phase one, several oil and gas EPC contracts were reviewed to identify the contractual position of the environmental management standards, rules and regulations, parameters and related costs. In the next step, the clients' / contractors' environmental responsibilities were specified in a contract environment based on IOGP documents. Next, the project management standards have been reviewed to identify the projects' execution phases. Oil and gas projects mostly have a construction nature. Therefore, the Morris Life Cycle [34] has been used to identify the project's executive phases.

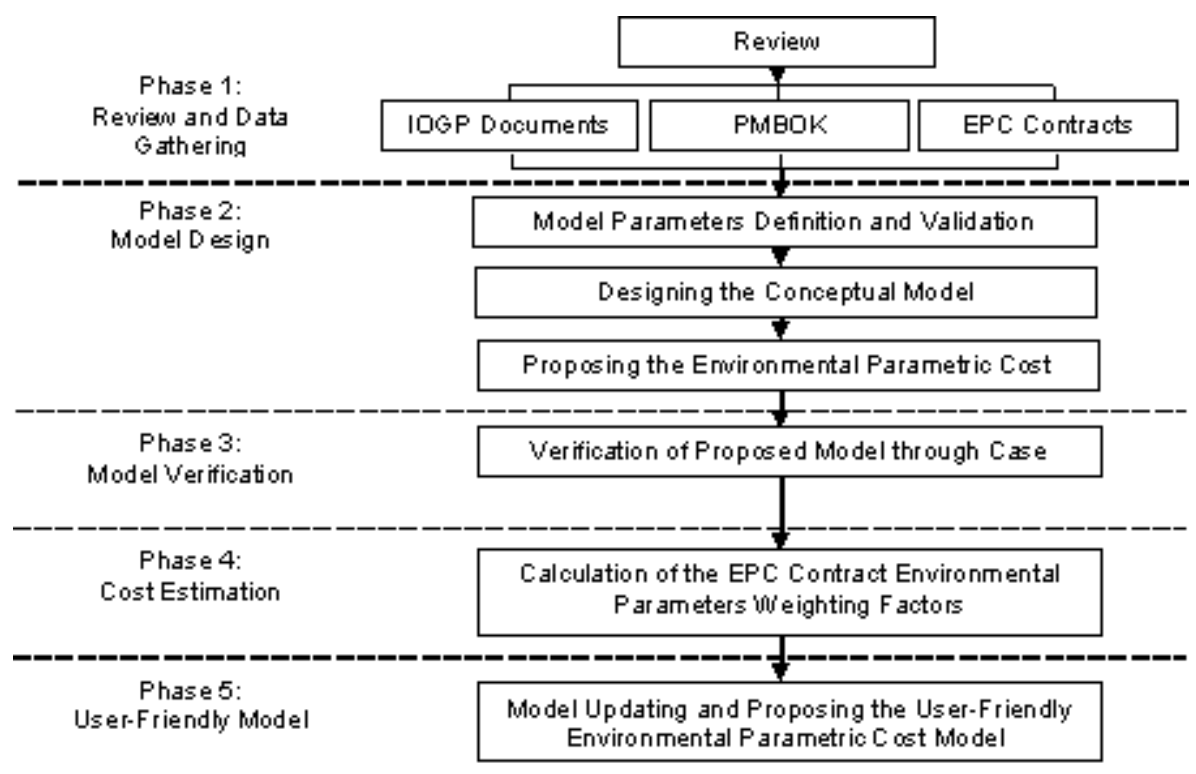

Figure 1. Methodology Flow Diagram. 
In phase two, as first step, the model parameters (environmental management's work packages) were defined for each executional phase and validated using the Delphi technique. The expert interview and checklist method was applied to validate the parameters. Using this information, a conceptual model was designed and accordingly an environmental parametric cost model was proposed. A case study was conducted as phase three on the Sirri Gas Gathering and NGL Recovery project located in the south of Iran. In phase four, weighting factors (WFs) of EPC contract's environmental parameters were calculated. In phase five, all calculations were updated up to 2015. At the end, a user-friendly environmental parametric cost model for EPC contracts was presented.

The cost estimation methods used in designed model were based on PMI standard [34] described as follows:

- The bottom-up cost estimation method was used to calculate the cost of each environmental management parameter (work package), separately;

- The group decision making technique (Delphi technique) was used to validate the identified environmental management parameters (work packages); and

- The parametric modelling was used to design the environmental parametric cost model.

\section{Results and Discussion}

The results of review and data gathering show that international and national standards and regulations are addressed in all oil and gas EPC contracts' clauses. Experiences indicate that the contractors interest in those contracts' clauses, which have direct financial effects on project execution. While, the key factors of a contract are the project technical information, predicted cost and time management; the invoices submitted by contractors only include the technical items and the position of environmental indicators is disregarded. It can result in contractors ignoring the proper implementation of environmental management and referring its execution to unskilled employees.

On the other hand, the WBS and CBS framework of EPC contracts and the case study project were reviewed to find the best position for the environmental management work packages in various project phases. The case study project's WBS and CBS data are used for cost management. Whereas, the general environmental legal requirements have been mentioned in oil and gas EPC contracts, there is not any specific clause for environmental management and also neither in related WBS and CBS. Furthermore, it was essential to review the WBS and CBS of other oil and gas EPC project contracts to determine the similarity degree of the contract type and the project control method applied. Results proved that all WBS and CBS structures are the same in the contractual framework and all environmental parameters shall be analyzed in following three sections: (1) Engineering and Management, (2) Procurement and (3) Construction, Commissioning, Start-up and Hand over.

\subsection{Model Parameters Definition and Validation}

In this study, two types of variables as independent and dependent ones were separately investigated. Accordingly, the project's total budget as independent variable and the environmental parameters, which have financial weight, as dependent variables were considered. To identify and validate research variables (environmental management parameters), field studies and interviews were conducted with 20 numbers of HSE managers, experts and specialists. Then, the HSE terms of EPC contracts were investigated. The Delphi technique was used to finalize the opinions of the environmental experts involved in the case study project including clients, contractors and sub-contractors' employees. Ultimately, the environmental management parameters were identified and finalized in terms of activity types (permanent or temporary), project execution phases and type of costs (fixed or variable costs) as shown in Table 1. 
Table 1. The cost of environmental management work packages in project phases (calculative criteria).

\begin{tabular}{|c|c|c|c|c|c|c|c|}
\hline \multirow[b]{2}{*}{ No. } & \multirow[b]{2}{*}{ Environmental Parameter } & \multicolumn{5}{|c|}{ Project Phases Cost (US \$) } & \multirow[b]{2}{*}{ Total Costs (US \$) } \\
\hline & & $\begin{array}{l}\text { Engineering and } \\
\text { Management }\end{array}$ & Procurement & Construction & Precomm. & $\begin{array}{l}\text { Comm., Start up } \\
\text { and Hand Over }\end{array}$ & \\
\hline 1 & Waste Management & & & & & & \\
\hline 1.1 & Industrial Waste Management & & & $299,534.4115$ & $122,526.4292$ & $133,413.8092$ & $555,474.65$ \\
\hline 1.2 & Camp and Offices Waste Management & & & $45,375.00314$ & $18,905.42986$ & $18,418.64368$ & $82,699.07668$ \\
\hline 1.3 & Waste Disposal Machinery & & $53,430.22013$ & & & & $53,430.22013$ \\
\hline 1.4 & Trash Bins and Bags for Sites and Camps & & & $30,504.94724$ & $10,907.25144$ & 5166.429552 & $465,787.62823$ \\
\hline 2 & Green Space and Planting & & & $134,830.9636$ & $10,469.82705$ & $10,200.24487$ & $15,501.0355$ \\
\hline 3 & Waste Water Treatment Package & & $491,558.0252$ & & & & $491,558.0252$ \\
\hline 4 & Waste Water Transportation Truck & & $117,546.4843$ & & & & $117,546.4843$ \\
\hline 5 & Environmental Measurement and Monitoring & & & $31,051.5591$ & 9576.709443 & 8300.821781 & $48,929.09032$ \\
\hline 6 & $\begin{array}{l}\text { Environmental Impact Assessment (EIA), } \\
\text { Environmental Base Study (EBS) }\end{array}$ & $55,297.50055$ & & & & & $55,297.50055$ \\
\hline 7 & Camp and Offices Hygiene and Sanitation & & & $173,937.512$ & $72,470.81445$ & $70,604.80076$ & $317,013.1273$ \\
\hline 8 & Monthly Drinking Water Laboratory Test & & & 3630.000251 & 1512.434389 & 1473.491494 & 6615.926134 \\
\hline 9 & Periodic Medical Examination and Check & & & $59,813.62204$ & $21,386.76752$ & $10,130.25402$ & $91,330.64359$ \\
\hline 10 & Project Environmental Team & & & $320,171.3714$ & $128,263.2446$ & $119,756.5535$ & $568,191.1695$ \\
\hline 11 & Personal Protective Equipment (PPE): & & & & & & \\
\hline 11.1 & Safety Shoe & & & $398,757.4803$ & $142,578.4502$ & $67,535.0268$ & $608,870.9573$ \\
\hline 11.2 & Safety Gloves (All Types) & & & $48,332.0230$ & $17,477.5973$ & 8648.4741 & $74,458.0944$ \\
\hline 11.3 & Safety Glasses/Face Shield & & & $60,856.66731$ & $18,535.19852$ & 8779.553486 & $88,171.41932$ \\
\hline 11.4 & Face Mask & & & $120,265.2561$ & $43,001.6606$ & $20,368.5641$ & $183,635.4807$ \\
\hline 11.5 & SCBA & & & 5770.4638 & 8507.4434 & & $14,277.9072$ \\
\hline 11.6 & Ear Muff/Plug & & & $11,324.7124$ & $14,314.8764$ & 6789.5167 & $32,420.1055$ \\
\hline 11.7 & Safety Helmet & & & $18,176.1340$ & & 4052.1016 & $22,228.2356$ \\
\hline 11.8 & Personal Detector/Alarm & & & & & $16,883.7567$ & $16,883.7567$ \\
\hline 12 & Gas Detector & & & 1068.604403 & 4726.357464 & & 5794.961867 \\
\hline 13 & Environmental Trainings & & & & & & \\
\hline 13.1 & Trainer & & & $167,994.8356$ & $66,078.37579$ & $61,710.30132$ & $295,783.5127$ \\
\hline 13.2 & Training Software, Films and Training CDs & & & $10,686.04403$ & & & $10,686.04403$ \\
\hline 13.3 & Temporary Training Facilities & & & 7693.951699 & & & 7693.951699 \\
\hline 14 & External Audits and Certification & & & 4150.41089 & 4150.41089 & 4150.41089 & $12,451.23267$ \\
\hline \multirow[t]{2}{*}{15} & EMS Establishment & $53,430.22013$ & & & & & $53,420.22013$ \\
\hline & Total Cost of Work packages & $108,727.7207$ & $662,534.7296$ & $1,953,925.974$ & $715,389.2785$ & $576,373.7546$ & $4,016,951.457$ \\
\hline
\end{tabular}




\subsection{Designing the Conceptual Model}

The method applied to design the environmental parametric cost model was based on Figure 2 . As indicated in the conceptual model, it is necessary to consider the environmental management costs in all project phases, separately.

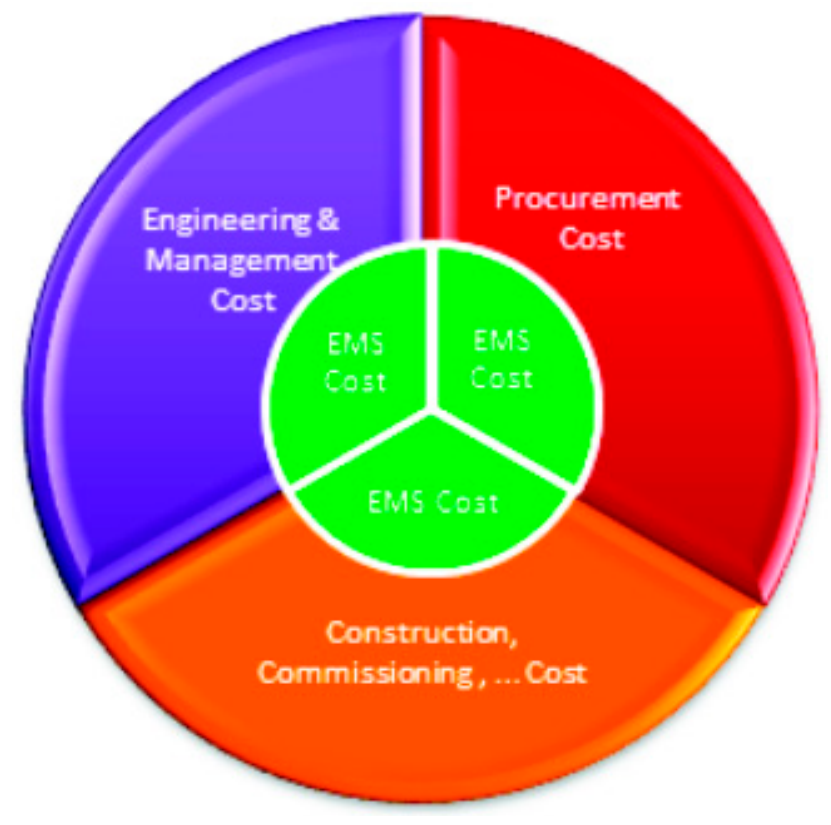

Figure 2. Conceptual model to estimate the EMS costs of oil and gas EPC projects.

\subsection{Designing the Environmental Parametric Cost Model}

The EPC projects total cost estimation basis is expressed in Equation (1). The abbreviations presented in mathematical equations are described in Table A1 of the Appendix A.

$$
\mathrm{PTC}=\mathrm{EM}_{\mathrm{C}}+\mathrm{P}_{\mathrm{C}}+\mathrm{CPCSH}_{\mathrm{C}}
$$

The method used for calculation of the environmental management cost of each project phase (as an independent parameter) was based on parametric modelling method as presented in Equation (2).

$$
\text { PEMS }_{C}=\sum_{i=1}^{\mathrm{n}} \mathrm{ECP}_{\mathrm{i}}
$$

To calculate the cost of each work package (parameter), the annual inflation rate compared to the project start year is required to be calculated separately during each project executional year. The cost calculation method for each work package is according to Equation (3).

$$
\begin{gathered}
\left.\mathrm{EP}_{\mathrm{C}}=\left[\left(\mathrm{nP}_{\mathrm{y} 1}\right) \times\left(\mathrm{C}_{\mathrm{y} 1}\right)\right]+\left[\left(\mathrm{nP}_{\mathrm{y} 2}\right) \times\left(\left(\mathrm{C}_{\mathrm{y} 1} \times \mathrm{IR}_{\mathrm{y} 1}\right) / 100\right)+\mathrm{C}_{\mathrm{y} 1}\right)\right]+\ldots+\left[\left(\mathrm{nP}_{\mathrm{yn}}\right) \times\left(\left(\mathrm{C}_{\mathrm{y}(\mathrm{n}-1)} \times\right.\right.\right. \\
\left.\left.\operatorname{IR}_{\mathrm{y}(\mathrm{n}-1)}\right) / 100\right)+\mathrm{C}_{\mathrm{y}(\mathrm{n}-1))]}
\end{gathered}
$$

where $\mathrm{EP}_{\mathrm{C}}$ : total cost of each environmental parameter during project executional years; $\mathrm{y} 1$ : first year of the project; yn: last year of the project; $\mathrm{nP}$ : required number of related parameters; $\mathrm{C}$ : the cost of each parameter; $\mathrm{C}_{\mathrm{y} 1}$ : the cost of the first year; and IR: annual inflation rate.

Considering the environmental management cost, the parametric model for cost estimation of EPC project different phases was presented in Equations (4)-(6):

$$
\mathrm{EM}_{\mathrm{C}}=\mathrm{M}_{\mathrm{C}}+\mathrm{BD}_{\mathrm{C}}+\mathrm{DD}_{\mathrm{C}}+\mathrm{EMS}_{\mathrm{C}}
$$




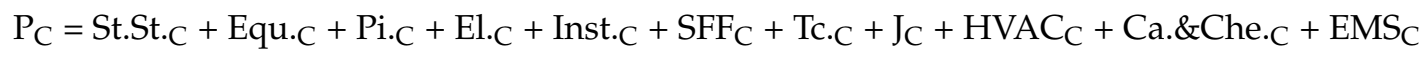

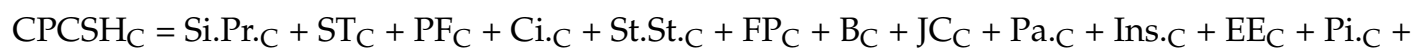

$$
\begin{aligned}
& \mathrm{El}_{\mathrm{C}}+\text { Inst. }_{\mathrm{C}}+\mathrm{TF}_{\mathrm{C}}+\mathrm{CC}_{\mathrm{C}}+\mathrm{SSC}_{\mathrm{C}}+\mathrm{VSPC}_{\mathrm{C}}+\mathrm{EMS}_{\mathrm{C}}
\end{aligned}
$$

Finally, the total environmental management cost of EPC projects was calculated based on Equation (7) as the basis of the designed conceptual model. Note that applied independent parameters in the environmental cost calculation of each projects' phases were used as a dependent parameter in the final estimation model and were presented in Equation (7).

$$
\mathrm{PT}_{\mathrm{EMSC}}=\mathrm{EM}_{\mathrm{EMSC}}+\mathrm{P}_{\mathrm{EMSC}}+\mathrm{CPCSH}_{\mathrm{EMSC}}
$$

\subsection{Verification of the Designed Model by Case Study}

To verify the designed model, the case study's data was used. The costs of environmental management's work packages were calculated for various project phases by using Equation (3) and the market-based price, taking into consideration the annual inflation rate (Table 1). According to Table 1 , construction phase dedicated as the most important environmental management cost of project.

The total environmental management cost for each execution phase of the Sirri NGL project is presented in Figure 3a. It can be seen that the maximum cost of environmental management $(49 \%)$ is allocated to the construction phase. Figure $3 \mathrm{~b}$ indicates that the environmental management cost in construction, pre-commissioning, commissioning, start up and hand over phases involve the most number of work packages in project cost $(81 \%)$. The portion of management and engineering and procurement phases is not comparable to that of construction, pre-commissioning, commissioning, start-up and hand over phases and it is nearly four times smaller. Therefore, it is necessary to emphasize control of the applied costs by contractors from construction phase to the end of the project.

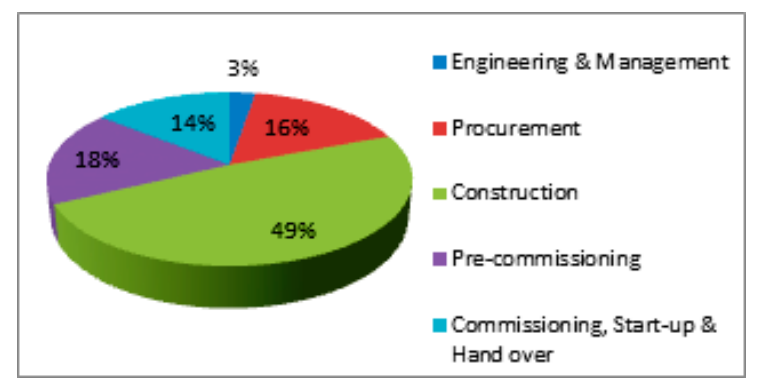

(a)

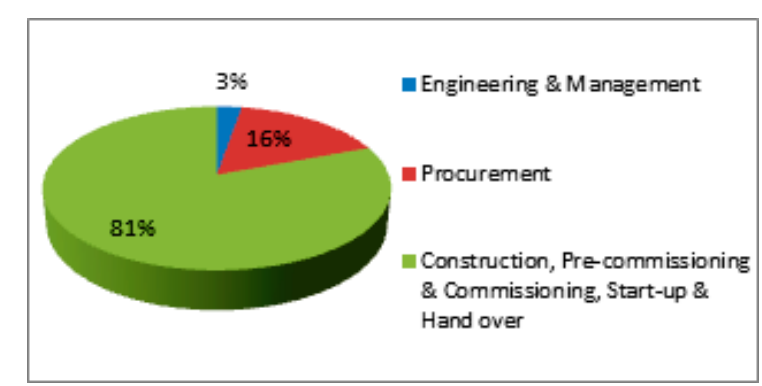

(b)

Figure 3. Environmental management costs of Sirri NGL project phases in (a) Each execution phase; (b) Cumulative phase.

Comparison of project environmental management costs in different project phases (Figure 4) shows that the maximum cost is related to industrial waste management, wastewater treatment package, the project environmental team and purchasing safety shoes. Other costs are almost at the same level.

The case study project's total cost (PTC) based on project's CBS is 458,302,940 USD using Equation (1). The total EMS costs for project $\left(\right.$ PEMS $_{C}$ ) is estimated as 4,016,951.457 USD by using Equation (2) and Table 1. It shall be noted that the cost of each EMS parameter in Table 1 is calculated using Equation (3). Moreover, the mathematical model for cost estimation of various phases in EPC projects is based on Equations (4)-(6). The criterion selected for cost estimation of each separate phase is based on the CBS adopted in the case study, which does not include the EMS criteria. The cost of the EMS work packages of each project phase should be considered in the project control system (WBS and CBS). Applying the EMS costs of each project phase, separately, the total EMS cost of NGL projects is calculated according to Equation (7) and Table 1. 


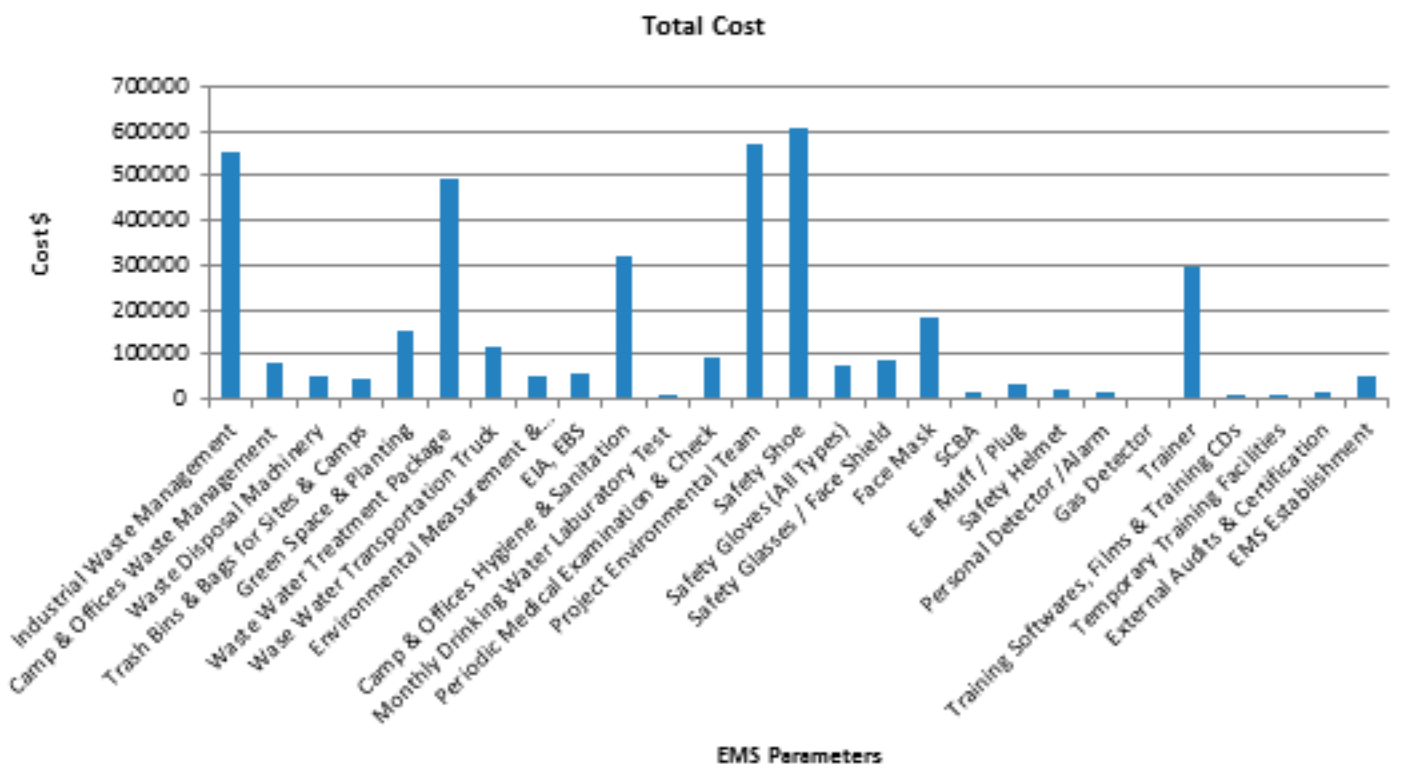

Figure 4. Estimated environmental costs of Sirri NGL project.

\subsection{Calculation of the EPC Contract Environmental Management Weighting Factors}

The weighting factors (WF) for each environmental parameter were calculated considering the project total cost and the environmental management costs. The WF for the whole project is presented in Equation (8).

$$
\mathrm{PTWF}=(\mathrm{WF} \%)_{\text {Tech. }}+(\mathrm{WF} \%)_{\mathrm{EMS}}
$$

Concerning Equation (7), the user-friendly parametric model for environmental management of EPC contracts is presented as Equation (9).

$$
\mathrm{EMS}_{\mathrm{C}}=\left[(\mathrm{EMS} \mathrm{WF} \%)_{\mathrm{EM}} \times \mathrm{PTC}\right]+\left[(\mathrm{EMS} \mathrm{WF} \%)_{\mathrm{P}} \times \mathrm{PTC}\right]+\left[(\mathrm{EMS} \mathrm{WF} \%)_{\mathrm{CPCSH}} \times \mathrm{PTC}\right]
$$

Table 2 shows the calculated environmental management WFs for case study project. Through this calculation method, the WF of each environmental work package can be easily determined and put into the project CBS.

Table 2. Weighting Factor (WF)\% for Sirri NGL execution phases and estimation of environmental management value.

\begin{tabular}{ccccc}
\hline \multirow{2}{*}{ Project Phases } & \multicolumn{2}{c}{ Contract Value } & \multicolumn{2}{c}{ Environmental Management Value } \\
\cline { 2 - 5 } & Amount (US \$) & WF\% & Amount (US \$) & WF\% \\
\hline Management \& Engineering & $20,996,820$ & $4.5814 \%$ & 108,728 & 0.023724046 \\
Procurement, Supply \& Transportation & $280,329,372$ & $61.1668 \%$ & 662,535 & 0.144562677 \\
Construction, Installation, & $156,976,747$ & $34.2517 \%$ & $3,245,689$ & 0.70819729 \\
Commissioning, Start \& Hand over & $458,302,940$ & $100.0000 \%$ & $4,016,952$ & 0.876484014 \\
Total & 458, &
\end{tabular}

Regarding to the designed environmental parametric cost model presented in Equation (8) and the value of environmental management, the total cost of case study project is calculated as following:

$$
\mathrm{PTWF}=(99.123515986 \%)_{\text {Tech. }}+(0.876484014 \%)_{\mathrm{EMS}}=100 \%
$$

The WF percentages for both different project phases and the defined environmental management are illustrated in Table 2 and Figure 5. 


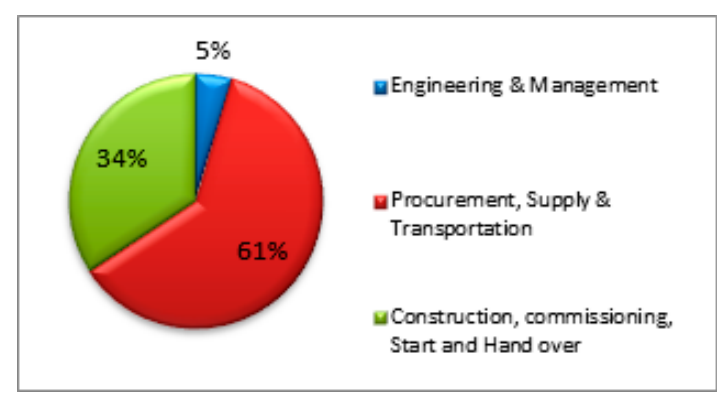

(a)

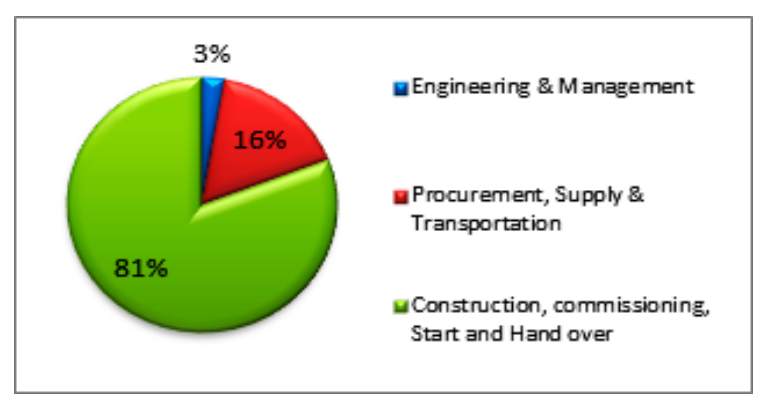

(b)

Figure 5. The WF\% of case study project in: (a) Project execution phase; (b) Environmental Management System.

According to Figure 5a, although the procurement, supply and transportation phase shows the maximum $\mathrm{WF} \%$ of $61 \%$ but its value in implementation of project environmental management is $16 \%$. On the other hand, the total project execution in construction, commissioning, start-up and hand over phase with the total WF of $34 \%$ has a higher importance than the total project execution in other phases. This phase, also, shows a WF of $81 \%$ for project environmental management and related work packages. Indeed, the high executional workload, establishment of environmental infrastructures, necessity for establishing a proper and efficient system, conducting training courses and environmental control are main factors in this phase. It is while the engineering and management phase with the WF of $5 \%$ (minimum financial value) in project and 3\% in environmental management has less financial importance, respectively.

In order to check the validation of the designed model and examine the trend of changes, it was essential to update all calculations for the case study project and recalculate the total project costs from 2011 to 2015. For this purpose, the annual guideline for the identification of work factors price list in oil and gas industry from 2007 to 2015 was used [35]. This guideline shows that the project price list was determined based on the annual inflation rate. Therefore, the related calculations were updated considering the annual inflation rate released by the Central Bank of Iran [36]. The updated WF\% for both different project phases and the defined environmental management indicates the stability of the applied coefficients in the designed model. Hence, the proposed parametric model can be used in other construction projects, as well. It should be noted that the model sensitivity might change depending on the type and required number of work packages over various time durations. In other words, it is possible that some work packages and related financial values would not be included in some contracts, depending on the nature of their activities.

\section{Conclusions}

In this study, a total of 30 environmental management work packages were identified and the related costs were separately calculated during the executional phases of oil and gas EPC projects. Through designing a parametric model, the WFs for environmental management parameters were calculated in comparison with the total project WFs. The estimated total environmental management costs indicate that the construction, commissioning, start-up and hand over phase includes a maximum value of $81 \%$ in comparison with the engineering and management and procurement, supply and transportation phases with a total of $19 \%$, while its environmental management WF is equal to $0.70 \%$ of the total project's WF. Therefore, it is necessary for project executive managers to place emphasis on the control of contractors' invoices during this phase.

Whereas the project's progress monitoring is based on WBS and CBS, the designed model can incorporate environmental management work packages' costs into the contracts. This model does not only control the environmental performance in the prequalification stage but also controls the project progress by merging environmental management work packages into the project WBS and CBS 
and approving the submitted invoices. Considering the necessity of environmental costs estimation during project phases, the presented model can identify those costs in the contract environment. Moreover, by presenting environmental management work packages, it specifies the WFs for the implementation of environmental management in comparison with the total project WF. Refer to the oil and gas contracts, the environmental budget has not been identified in CBS and the work packages have not been defined. The findings show that the allocated environmental budget in oil and gas micro and mega contracts has not been clearly defined and related costs are paid depending on the contractors' willingness.

A review of different contracts specified that the contractors' environmental performance depend on allocated budget and the predicted required resources. Thus, no appropriate implementation by the contractors is performed. Furthermore, headline of environmental management budget shall be defined in WBS and CBS. Otherwise, contractors cannot improve their environmental performance without proper investment in this section. In fact, the environmental legal requirements have been identified in EPC projects, while, the payment conditions of invoices have not been specified. This indicates a serious management conflict.

While the environmental management work packages are not systematically defined in contracts, the execution of this section depends on contractors' culture. As a separate and transparent budget is not allocated, the environmental management cannot be implemented properly. Lack of environmental cost estimation causes incorrect and unmanaged implementation of environmental management in oil and gas mega contracts and results in irreparable losses on human health, equipment and the environment.

In this research, it is only considered the executional environmental management costs, which can affect the total cost of oil and gas projects. To improve the environmental cost management in oil and gas industries it is recommended to divide the project environmental costs in external and internal costs.

1. Internal costs of projects included:

- Environmental Pollution Prevention Costs: The costs of activities to prevent the production of pollutants including pollution control equipment, designing processes, designing products and carrying out environmental studies.

- Environmental Detection Costs: The costs of compliance with appropriate environmental standards.

- Environmental Internal Costs: The costs of remedial actions to eliminate and manage the wastes produced including the costs for operating pollution control equipment, licensing facilities for producing pollutants and costs resulting from recycling scrap.

2. External costs of projects included environmental degradation costs and human impact costs.

Acknowledgments: The authors received no financial support for the research.

Author Contributions: Sanaz Toutounchian, with assistance of Madjid Abbaspour and Tooraj Dana, conceived and designed the experiments and conceptual model. Sanaz Toutounchian, Solmaz Toutounchian and Tooraj Dana provided necessary data from EPC contracts. In the next step, Sanaz Toutounchian and Tooraj Dana analyzed the data from case study. At the field of methodology, all authors contributed. For conclusion, Sanaz Toutounchian, Solmaz Toutounchian and Zahra Abedi tried. Sanaz Toutounchian wrote the paper and other authors tried to improve it.

Conflicts of Interest: The authors declare no conflict of interest. 


\section{Appendix A}

The list of Abbreviations, which were used in equations, is as Table A1.

Table A1. List of Abbreviations.

\begin{tabular}{|c|c|}
\hline Description & Abbr. \\
\hline Building Cost & $\mathrm{B}_{\mathrm{C}}$ \\
\hline Basic Design Cost & $\mathrm{BD}_{\mathrm{C}}$ \\
\hline Catalyst \& Chemicals Cost & Ca.\&Che.C \\
\hline Construction Camp Cost & $\mathrm{CC}_{\mathrm{C}}$ \\
\hline Civil Cost & Ci.C \\
\hline Construction, Pre-comm., Commissioning, Start-up and Hand-Over Cost & $\mathrm{CPCSH}_{\mathrm{C}}$ \\
\hline Detail Design Cost & $\mathrm{DD}_{\mathrm{C}}$ \\
\hline Environmental Base Study & EBS \\
\hline Environmental Cost & $\mathrm{EC}$ \\
\hline Equipment Erection Cost & $\mathrm{EE}_{\mathrm{C}}$ \\
\hline Environmental Impact Assessment & EIA \\
\hline Electrical Cost & El.C \\
\hline Engineering \& Management Cost & $\mathrm{EM}_{\mathrm{C}}$ \\
\hline Environmental Management System & EMS \\
\hline Environmental Management System Cost & EMS $_{\mathrm{C}}$ \\
\hline Engineering, Procurement and Construction & $\mathrm{EPC}$ \\
\hline Environmental Parameters Cost & $\mathrm{EP}_{\mathrm{C}}$ \\
\hline Equipment Cost & Equ.c \\
\hline Fire Proofing Cost & $\mathrm{FP}_{\mathrm{C}}$ \\
\hline Health, Safety and Environmental Management System & HSE-MS \\
\hline Insulation Cost & Ins.C \\
\hline Instrument Cost & Inst. $C$ \\
\hline International Association of Oil and Gas Producers & IOGP \\
\hline Inflation Rate & IR \\
\hline Jetty Cost & $\mathrm{J}_{\mathrm{C}}$ \\
\hline Jetty Construction Cost & $\mathrm{JC}_{\mathrm{C}}$ \\
\hline Management Cost & $\mathrm{M}_{\mathrm{C}}$ \\
\hline Parameter & $\mathrm{P}$ \\
\hline Painting Cost & Pa.c \\
\hline Procurement Cost & $\mathrm{P}_{\mathrm{C}}$ \\
\hline Project EMS Cost & PEMS $_{C}$ \\
\hline Piling \& Foundation Cost & $\mathrm{PF}_{\mathrm{C}}$ \\
\hline Piping Cost & Pi.C \\
\hline Project Total Cost & PTC \\
\hline Project Total EMS Cost & $\mathrm{PT}_{\mathrm{EMSC}}$ \\
\hline Project Total Weighting Factor & PTWF \\
\hline Safety \& Fire Fighting Cost & $\mathrm{SFF}_{\mathrm{C}}$ \\
\hline Site Preparation Cost & Si.Pr.C \\
\hline Support Service to Client Cost & $\mathrm{SSC}_{\mathrm{C}}$ \\
\hline Storage Tanks Cost & $\mathrm{ST}_{\mathrm{C}}$ \\
\hline Steel Structure Cost & St.St.C \\
\hline Telecommunication Cost & Tc.c \\
\hline Technical & Tech. \\
\hline Temporary Facility Cost & $\mathrm{TF}_{\mathrm{C}}$ \\
\hline Vendor Staff and Pre-comm. \& Commissioning Cost & VSPC $_{C}$ \\
\hline
\end{tabular}

\section{References}

1. Project Management Institute (PMI). A Guide to the Project Management Body of Knowledge (PMBOK Guide), 2000 ed.; Project Management Institute: Newtown Square, PA, USA, 2001; ISBN 1-880410-22-2.

2. IOGP (International Association for Oil and Gas Producers). HSE Management-Guidelines for Working Together in a Contract Environment; Report No. 423; International Association for Oil and Gas Producers: London, UK, 2014. 
3. Hofer, C.; Cantor, D.; Dai, J. The competitive determinants of a firm's environmental management activities: Evidence from US manufacturing industries. J. Oper. Manag 2012, 30, 69-84. [CrossRef]

4. De Burgos-Jimenez, J.; Vazquez-Brust, D.; Plaza-Ubeda, J. Environmental protection and financial performance: An empirical analysis in Wales. Int. J. Oper. Prod. Manag. 2014, 33, 981-1018. [CrossRef]

5. Muhammad, N.; Scrimgeour, F.; Reddy, K.; Abidin, S. The Relationship between Environmental Performance and Financial Performance in Periods of Growth and Contraction: Evidence from Australian Publicly Listed Companies. J. Clean. Prod. 2015, 102, 324-332. [CrossRef]

6. Dam, L.; Petkova, B. The impact of environmental supply chain sustainability. Int. J. Oper. Prod. Manag. 2014, 34, 586-609. [CrossRef]

7. De Giovanni, P. Do internal and external environmental management contribute to the triple bottom line? Int. J. Oper. Prod. Manag. 2012, 32, 265-290. [CrossRef]

8. Montabon, F.; Sroufe, R.; Narashimhan, R. An examination of corporate reporting, environmental management practices and firm performance. J. Oper. Manag. 2007, 25, 998-1014. [CrossRef]

9. Rao, P.; Holt, D. Do green supply chains lead to competitiveness and economic performance? Int. J. Oper. Prod. Manag. 2005, 25, 898-916. [CrossRef]

10. Darnall, N.; Edwards, D. Predicting the cost of environmental management systems adoption: The role of capabilities, resources and ownership structure. Strateg. Manag. J. 2006, 27, 301-320. [CrossRef]

11. Chou, J.S. Generalized linear model-based expert system for estimating the cost of transportation projects. Expert Syst. Appl. 2009, 36, 4253-4267. [CrossRef]

12. Czarnigowska, A.; Sobotka, A. Time-Cost relationship for predicting construction duration. Arch. Civ. Mech. Eng. 2013, 13, 518-526. [CrossRef]

13. Hola, B.; Schabowicz, K. Estimation of earth works execution time and cost by means of artificial neural networks. Autom. Constr. 2010, 19, 570-579. [CrossRef]

14. Kim, D.Y.; Han, S.H.; Kim, H.; Park, H. Structuring the prediction model of project performance for international construction projects: A comparative analysis. Expert Syst. Appl. 2009, 36, 1961-1971. [CrossRef]

15. Lai, Y.T.; Wang, W.C.; Wang, H.H. AHP-and simulation-based budget determination procedure for public building construction projects. Autom. Constr. 2008, 17, 623-632. [CrossRef]

16. Magnussen, O.M.; Olsson, N.O.E. Comparative analysis of cost estimates of major public investment projects. Int. J. Proj. Manag. 2006, 24, 281-288. [CrossRef]

17. Rogalska, M.; Bożejko, W.; Hejducki, Z. Time/cost optimization using hybrid evolutionary algorithm in construction project scheduling. Autom. Constr. 2008, 18, 24-31. [CrossRef]

18. Wang, Y.R.; Gibson, G.E., Jr. A study of preproject planning and project success using ANNs and regression models. Autom. Constr. 2010, 19, 341-346. [CrossRef]

19. Curkovic, S.; Sroufe, R. Total Quality Environmental Management and Total Cost Assessment: An exploratory study. Int. J. Prod. Econ. 2007, 105, 560-579. [CrossRef]

20. Jasinski, D.; Meredith, J.; Kirwan, K. A comprehensive review of full cost accounting methods and their applicability to the automotive industry. J. Clean. Prod. 2015, 108, 1123-1139. [CrossRef]

21. Henri, J.F.; Boiral, O.; Roy, M.J. Strategic cost management and performance: The case of environmental costs. Br. Account. Rev. 2015, 48, 269-282. [CrossRef]

22. Pizzini, M.J. The relation between cost-system design, managers' evaluations of the relevance and usefulness of cost data, and financial performance: An empirical study of US hospitals. Account. Org. Soc. 2006, 31, 179-210. [CrossRef]

23. Maiga, A.S.; Nilsson, A.; Jacobs, F.A. Assessing the interaction effect of cost control systems and information technology integration on manufacturing plant financial performance. Br. Account. Rev. 2014, 46, 77. [CrossRef]

24. De Beer, P.; Friend, F. Environmental accounting: A management tool for enhancing corporate environmental and economic performance. Ecol. Econ. 2006, 58, 548-560. [CrossRef]

25. Frost, G.R. The introduction of mandatory environmental reporting guideline: Australian evidence. ABACUS J. Account. Financ. Bus. Stud. 2007, 43, 190-216. [CrossRef]

26. Edino, M.O.; Nsofor, G.N.; Bombom, L.S. Perceptions and attitudes towards gas flaring in the Niger Delta, Nigeria. Environmentalist 2010, 30, 67-75. [CrossRef]

27. Beck, A.C.; Campbell, D.; Shrives, P.J. Content analysis in environmental reporting research: Enrichment and rehearsal of the method in a British-German context. Br. Account. Rev. 2010, 42, 207-222. [CrossRef] 
28. Russell, A.; Jenkins, L. Reflections on the attempt to set a comprehensive international accounting standard for the oil and gas industry. Petrol. Account. Financ. Manag. J. 2010, 29, 16-29.

29. Duriau, V.K.; Reger, R.K.; Pfarrer, M.D. A content analysis of the content analysis literature in organization studies: Research themes, data source, and methodological refinements. Organ. Res. Methods 2007, 10, 5-34. [CrossRef]

30. Olalekan, I.O.; Jumoke, O.O. Identifying barriers to environmental management accounting practices: A comparative study of Nigerial and Couth Africa practices. Bus. Manag. Rev. 2017, 9, 168-179.

31. Bassy, E.B.; Oba, U.E.U.; Onyah, G.E. An analysis of the extent of implication of environmental cost management and its impact on output of oil and gas companies in Nigeria (2001-2010). Eur. J. Bus. Manag. 2013, 5, 110-119.

32. Can, A.I.M.S.K.; Etale, L.M.; Frank, B.P. The impact of environmental cost on corporate performance: A study of oil companies in Niger Delta states of Nigeria. J. Bus. Manag. 2013, 2, 1-10. [CrossRef]

33. Ezejiofor, R.A.; Racheal, J.A.; Chigbo, C.B.E.E. Effect of sustainability environmental cost accounting on financial performance of Nigerian corporate organizations. Int. J. Sci. Res. Manag. Stud. 2016, 4, 4536-4549. [CrossRef]

34. Project Management Institute (PMI). A Guide to the Project Management Body of Knowledge (PMBOK Guide), 5th ed.; Project Management Institute: Newtown Square, PA, USA, 2013; ISBN 978-1-935589-67-9.

35. Ministry of Petroleum of Iran. Specific Price List for Oil and Gas Facilities-Specific Price for Oil Industries Activities for 2015; Deputy of Engineering: Tehran, Iran, 2014.

36. Central Bank of Iran. Total Price List and Consumable Services Index in the Iranian Urban Areas (Inflation Index): Annual Figures of Inflation Rate and Index during 1936-2014; Central Bank of Iran: Tehran, Iran, 2015. Available online: http:/ / www.cbi.ir/datedlist/10807.aspxf (accessed on 16 August 2016).

(C) 2018 by the authors. Licensee MDPI, Basel, Switzerland. This article is an open access article distributed under the terms and conditions of the Creative Commons Attribution (CC BY) license (http:/ / creativecommons.org/licenses/by/4.0/). 